\title{
THE REGIONAL INNOVATION POTENTIAL OF INDUSTRIAL CLUSTERS
}

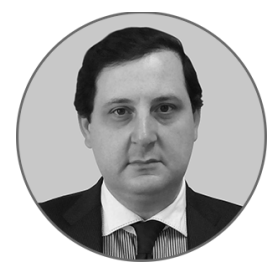

\author{
Ruslan A. ABRAMOV \\ Plekhanov Russian University of Economics, Moscow, Russian Federation \\ oef08@mail.ru
}

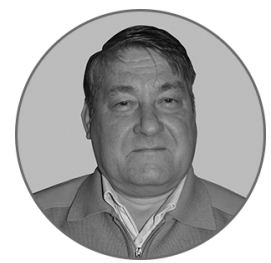

\section{Sergei K. PODCHUFAROV}

Plekhanov Russian University of Economics, Moscow, Russian Federation

Sergey_pod@bk.ru

Corresponding author

\section{Article history:}

Received 23 November 2016

Received in revised form

21 February 2017

Accepted 24 March 2017

Translated 25 May 2017

Available online 15 June 2017

JEL classification: B52, D23

Keywords: regional clusters, production system, business competitiveness, economic policy, simulation, development

\begin{abstract}
Importance The article discusses the aspects of increasing the innovative activity of regions and industry clusters. Objectives The article purports to show how the strategy of enhancing the competitiveness of the economy of the Russian Federation is implemented in a key cluster of the country's development, namely in the regions of the Central Federal District.

Methods We used analytical, forecasting and expert methods, as well as a mathematical modeling technique for adjusting the cluster estimates.

Results The article says there is a need for certain activities to make network innovation structures in the regions on the basis of a cluster approach, include certain measures to support the development of national and regional high-priority clusters in programs of regional development, attract scientific and educational centers to study the world experience of cluster development, and train professionals for work under the conditions of cluster formation of the economy.

Conclusions and Relevance Formation of clustered entities should be based on strategic decisions made in relation to profit control associated with the stages of social reproduction. The formation and development of clusters lead to many integral advantages at the region and country levels.
\end{abstract}

๔ Publishing house FINANCE and CREDIT, 2016

The editor-in-charge of this article was Irina M. Komarova

Authorized translation by Irina M. Komarova

Studying the cluster interaction processes of innovative entities goes beyond a simple search for available resources needed to increase the profitability. It becomes important to identify criteria and factors for assessing the communicative capabilities of entities and use these capabilities to activate cluster interaction processes and multiply competitive advantages for each party [1].
To evaluate resource-based aspects of the innovative potential of the cluster environment and push ahead information and communicative processes of industrial enterprises within the cluster to interact, we point out the following information streams [2]:

- those reflecting the market situation;

- those flowing from other parties of the cluster; 
- those proceeding from local and central authorities;

- those proceeding from infrastructure entities;

- internal information flows of companies.

Considering that there may be certain managerial constraints in the communication of cluster actors, adequate and appropriate information flows may depend on the following aspects [3]:

- geographical distance between the recipient and the source;

- average rapidity of data proliferation within the single information space;

- rapidity of the decision-making process and changes in the system components.

We believe the first two factors have a slight effect on the efficiency of the cluster structure management during the intensive technological progress in information and communications, while the third factor is decisive for the reduction of transaction costs incurred to ensure the efficiency of the cluster interactions $[4,5]$.

To benefit from innovative capabilities of the enterprises within the cluster, it is reasonable to determine key criteria and indicators of cluster interactions and subsequently analyze internal and external ties. It will help to boost the sustainability, integrity, competitiveness of each cluster resident (Tab. 1).

When formulating a relevant innovative strategy of the cluster and supporting entities' activities within the cluster, it is necessary to analyze the innovative potential of the entities, determine the analysis steps, configure an evaluation of internal ties among various communication types, which generate a synergistic effect [7].

We propose an approach to identifying values of cluster entities, reveal intrinsic contradictions and possible conflicts of interests. It will allow for the robust relationship management and create mutual confidence [8]. We assume, if the innovative potential of the cluster interactions is comprehensively evaluated, each cluster entity will be able to take advantage of it [9].

Summarizing the existing conceptual approaches to the interaction of entities in industrial clusters, we can trace what factors unleash the potential for industrial entities to interact within the cluster.
In our opinion, principal regulators that influence interactions of entities within the cluster locally, nationally, and globally, include governmental institutions, innovative development level of the industry and the so called hard and soft intellectual tools of the information and innovative framework, local initiatives and the rate of growth in the cluster interactions that are dependent on some functions (Tab. 2).

We examined what became the starting point for the creation of clusters in industrial sectors of various counties, such as Japan, United States of America, Austria, Germany and others. We found two principal ways how entities start their cooperation and subsequently create a cluster.

As envisaged by the first approach, interactions are spontaneous in new clusters, and mainly initiated in the business environment - the so called endogenous regulators. As for the second approach, a cluster may spring from the external business environment, i.e. authorities, higher schools, research institutions the exogenous regulators [11].

However, when the cluster evolves, some aspects of its external and internal environment change. As a result, business structures, higher schools, local authorities, public communities and information and communication infrastructure become regulators of this development.

In this research, factors of cluster interactions shall mean an array of stimulating and inhibiting exogenous and endogenous variable conditions that directly or indirectly influence the current state and strategic goals of an innovative cluster. Both external (exogenous) and internal (endogenous) factors are important to trigger interactions of IT-entities and other residents of the cluster. We analyzed premises for cluster interactions and discovered that such cluster interactions stem from incentives (positive factors) and disincentives (negative factors) that result from the exogenous and endogenous background [12].

To effectively support and develop cluster communications, the European Commission believes the following aspects should be settled:

- the extent to which know-how technologies of the cluster should be used;

- accessibility of the information system for certain partners;

- types of communication tools. 
Hence, it is possible to say that the high level of information and communication activities contributes to the successful cooperation within the cluster. The level of communications shapes the cooperation among the cluster entities. Interactions within the cluster create specific advantages as compared with interactions of companies out of any network. The effective innovative development of entities in the cluster often begins when the ultimate product or services or marketing processes are improved, since their spectrum and quality increase. These factors relate to communications modeled as the consumer - business, business - business, business - institutions. These patterns may distort formal and informal communication of entities ${ }^{1}$.

Appropriate business training and education also streamline cluster interaction processes, since they considerably enhance the cultural level of local entrepreneurship. Managers and leaders of innovative enterprises have to use modern information technologies in their activities, create web sites using up-to-date digital technologies, including e-communication means:

- Business to Business (B2B);

- Business to Citizens (B2C);

- Government to Business (G2B);

- Government to Citizens (G2C);

- Citizens to Community (C2C).

Partners are often not very confident in each other because governmental parties are not quite transparent and open. Confidence and trust are among the main drivers of cluster interactions, since they stimulate sharing of knowledge, expertise, technology, and ensure fair business, mutual support and focus on the network partnership. Confidence also results from congruous communications within the cluster, especially in case of joint project implementation [13].

Communications and cooperation within the cluster may often be affected and destroyed if partners are not cognizant of mutual needs. Informal communications are the underlying method to agree and coordinate activities within the cluster. However, as some foreign experts in the network initiative say, would-be cluster residents face certain mental barriers that make

\footnotetext{
${ }^{1}$ Pavlov K.V., Ratvortseva S.N., Cherepovskaya N.A. [A methodological approach to identifying potential clusters in regional economy]. Regional'naya ekonomika: teoriya I praktika = Regional Economy: Theory and Practice, 2015, no. 10, pp. 15-26. (In Russ.)
}

managers believe that cooperation with others will do more harm than good. In opinion of willing cluster residents, any threats usually arise from the theft of ideas and tampering with human resources. Conceptually, the cluster should have well-organized communications, thus streamlining the exchange of information and knowledge.

Endogenous disincentives may include:

- fragile ties of industrial enterprises with higher schools, other business structures and the social welfare sector of the region. It causes a lack of information on the local market needs;

- insufficient communication activities of teachers and researchers, and shortage of business communication specialists in enterprises and governmental bodies;

- absence of a coherent system of electronic communications;

- imperfect innovation infrastructure of cluster residents;

- insufficient applicability of staff training programs for market needs.

Exogenous factors obstructing cluster interactions include:

- insufficient development of governmental support mechanisms for innovative enterprises;

- absence of systemic and long-term governmental support to the information and communications sector;

- insufficient confidence in the government, etc.

Tab. 3 summarizes incentives and disincentives of cluster interactions and points them out as exogenous and endogenous factors of cooperation development.

We analyzed the sectoral location of clusters using methods proposed by I.E. Risin and co-authors [14]. Tab. 4 indicates the extent to which the regions in the Central Federal District are prepared for innovative activities. Cells are left blank if a coefficient is insignificant. Although blank cells are not preferable, we think it is reasonable to use this technique for making our findings more illustrative.

In our opinion, localization coefficients allow to evaluate the clustering conditions from two perspectives:

- localization level (coefficient value); 
- the extent of spatial diversification of industries (the number of regions where the coefficient is more than 1).

The combination of high regional localization and low spatial diversification is a perfect scenario, since it makes the competition as low as possible at the sectoral and regional levels. As the regional localization decreases and spatial diversification increases, the competition of sectors and regions becomes more intensive and clustering conditions deteriorate. In this respect, we can articulate six options of clustering conditions by level of localization and diversification.

Thus, in the Central Federal District, clustering processes are seen in those regions, which are able to earmark funds for developing their own clustering system. This method allows to determine the cluster condition and evaluate resources for its creation. The method should be specified for a probable synergistic regional market. The cluster strategy should be backed with original solutions and ideas that are different from the competitors' ones and focused on the protection of each entity's profit as part of a common portfolio of products offered by the cluster entities. Summarizing these theoretical ideas, we assume the profit area as the modified chain 'Demand-Goods-Revenue-Profit' in the cluster can be located in the area of procurement, production, distribution, sale, thus reflecting all consecutive stages of the social reproduction process (provided that the procurement area is included into the production process).

It is also worth mentioning that cluster development strategies are multipolar - growth, business reduction and liquidation, rearrangement of financial flows, licensing and business development abroad. Strategic planning tools (matrix models of portfolio analysis) often provide contradictory or ambiguous recommendations.

In our opinion, the following algorithm would be reasonable to articulate a cluster development strategy:

- formation of the aggregate product portfolio that indicates servicing subdivisions concentrated in the corporate management center;

- analysis of opportunities and threats in relation to each firm and cluster;

- analysis of the competitive potential and significance of firms for a target market;
- grouping of enterprises from perspectives of self-sufficiency, needs for additional investment and the development dead-end;

- intention to develop a new business area or a spin-off from the existing structures;

- preparation of a long-term program for developing a product portfolio by strategy of growth, cream skimming or elimination;

- coordination and synergy of production, marketing and social security policies within an entity and cluster, as a whole;

- PR-programs and participation in urban activities (sports, festivals, spring cleaning), lobbying of interests in local authorities;

- setting up the internal business balance and general financial plan of the cluster.

Principal criteria for such grouping include the potential of foreign markets, sales margin, specific weight among competitors in the market, effect of exit barriers.

The potential of sectoral markets are proposed to regard as the ratio of productive capacity of a cluster to total capacity of regional (national) markets from the existing production base and distribution network (the highest market share indicator). The range from 20 to 60 percent is considered as the most stable interval. The market share overrun entails additional expenditures, i.e. tolerance to competitors' attempts, product promotion, evasion from anti-monopoly policies of the State. When the entity does not have sufficient production capacities, it will not be able to benefit from the effect of scale in the mass market servicing.

Tab. 5 provides indicators to compare the extent to which clusters are strategically protected from competitors in terms of comprehensive product portfolio of the cluster.

To locate the cluster in the matrix, we should compute values of indicators - (1-9) as real numbers and (10-20) as binary numbers in line with a paired correlation of the latter, and assess the $x$ - and $y$-axes using the formulas:

$$
\begin{aligned}
& K_{z(x)}=\sum_{a=1}^{9} d_{a} K_{a} ; \\
& d_{a}=\frac{Y_{a}}{\sum_{a=1}^{9} Y_{a}} ;
\end{aligned}
$$




$$
\begin{aligned}
& \sum_{a=1}^{9} d_{a}=1 ; \\
& K_{z(y)}=\sum_{a=10}^{20} K_{a},
\end{aligned}
$$

where $K_{z(x)}$ is a component of the marketing potential of the strategy security of the cluster, $x$-axis in the coordinate plane, particles;

$a$ means the types of strategic safeguards of the cluster, $a=(1,20), \quad a \in N$;

$d_{a}$ is a weight coefficient of the $a$-type safeguard, $a=(1,20)$;

$K_{a}$ is a coefficient of the significance of the $a$-type safeguard, $a=(1,20)$;

$Y_{a}$ is a ranking coefficient of the strategic security of the cluster, $a=(1,20)$;

$K_{z(y)}$ is a component of the innovative and production potential of the cluster security, $y$-axis in the coordinate plane, particles.

Considering the nature of marketing potential indicators, which are relative values of the structure and have different averages ( 0.5 and 3 respectively), we can determine the right bound of the matrix as $x_{2}=2$ and the median interval of the model as $x_{1}=1$. The right bound of the matrix is set at the new maximum $x_{2}$, provided the inequality is in place:

$$
x_{2}=\left\{\begin{array}{cc}
x_{2}, & \text { if } \max \left(K_{z(x) l}\right) \leq 2 ; \\
\max \left(K_{z(x) l}\right), \text { if } \max \left(K_{z(x) l}\right)>2
\end{array}\right\},
$$

where $/$ is the number of entities within the cluster or the number of competitors in the market, $l \in N$.

To fulfill the condition in relation to $\max \left(K_{z(x))}\right) \leq 2$, $K_{a l}$ should satisfy the inequality:

$$
\sum_{a=1}^{9} K_{a}>18 \text {. }
$$

To ensure the medium and high security of the cluster, there should be the following conditions:

$$
\begin{aligned}
& \forall K_{z(x)} \geq 1 ; \\
& \sum_{a=1}^{9} K_{a}>9 .
\end{aligned}
$$

This right bound fluctuates when $x_{1}=1$ is pegged at the median interval, thus shaping a new approach to positioning - catching up with the leader, when the synergism of the leading entity determines the position of competing groups in the market and attributes them to the moderate or high security classes. The group with low security is static, however, it can horizontally migrate within the matrix towards the middle security class if the synergy of the entire cluster rises or its separate components get more specialized.

Likewise it is possible to forecast the development of other entities and their clusters in the market. However, the marketing component of the security is more dynamic. It was taken as a base to choose an independent variable for a two-dimensional model. The effect is supposed to synergetically build up without an additional increment in the production base (dependent variable).

The practical relevance of the model is that innovative and marketing potential indicators are versatile, thus allowing to compare clusters in terms of product portfolios of entities and sectoral markets for a certain diversified entity. Hence, they can be used in the matrix, The Potential of the Market and Competition. Considering that Tab. 5 presents marketing and innovative potential indicators as real and binary numbers, formulas for assessing the integral indicator of the competitiveness of the cluster may be as follows:

$$
\begin{aligned}
& K_{z}=\sum_{a}^{9} d_{x a} K_{a}+\sum_{a=10}^{20} d_{y a} K_{a} ; \\
& d_{x a}=\frac{Y_{a}}{\sum_{a=1}^{9} Y_{a}} ; \\
& d_{y a}=\frac{Y_{a}}{\sum_{a=1}^{20} Y_{a}} ; \\
& \sum_{a=1}^{9} d_{x a}=1 ; \\
& \sum_{a=10}^{20} d_{y a}=1,
\end{aligned}
$$

where $a$ means the types of strategic safeguards of the cluster, $a=(1 ; 20), \quad a \in N$;

$d_{x a}$ is the significance of safeguards for real indicators of the marketing potential, $a=(1 ; 9)$ particles;

$d_{y a}$ is the significance of safeguards for binary indicators of the innovative potential, $a=(10 ; 20)$ particles. 
This approach is more convenient in case of a repetitive analysis of the market and competitors, especially when the market is growing and the market growth trends are monitored and recorded in the coordinate plane. It is also practicable for forecasting the market competition after innovation and respective activities of competitors are implemented.

In our opinion, as an alternative program for the national economy development, it would be reasonable to create clusters in the high technology sector and old industrial regions so to advance entities that are joint from perspectives of technology, geography and distribution.

The salience of this cluster is that it depends on substantial capital expenditures and current assets for the following purposes:

- basic and applied researches for developing, designing technologies, manufacturing and operation of advanced technological equipment;

- manufacturing, transportation and mounting;

- construction of buildings, facilities and infrastructure;

- purchase of raw materials and energy sources, supplier credit, primarily, running flows of semi-finished products within the cluster;

- development of the social infrastructure, since enterprises in old production regions are pivots for entire localities, or house harmful or high-injury production.

The clustering process implies the vertical integration of respective production facilities of a technological chain and may involve:

- suppliers of raw materials and energy;

- manufacturers of power engineering and heavy engineering machines and equipment;

- construction organizations;

- financial institutions;

- research and development institutions;

- transport and trade intermediaries, entities of organizational infrastructure for business;

- waste recycling and disposal enterprises, and enterprises supplying the public with heat power and combustible gas energy;

- social infrastructure enterprises dealing with part-time employment of people working in backbone enterprises, and recreation entities.
Clustering processes are insufficiently spread in the Russian Federation due to the following reasons, we suppose:

- protracted economic and political crisis following the economic transformation of the country, and the global financial crisis;

- ineffective governmental regulation of innovation through tax, financial, customs and depreciation mechanisms;

- timing inconsistency in the adoption of laws, codes, subordinate laws on the innovative sector, discrepancies among them, frequent amendments, and abolishment of regulations, lack of legislative support to clustering processes;

- drastic reduction of governmental orders and demand for innovative products, goods, services, especially in high-tech activities (aerospace, defense, machine-building, shipbuilding, electronic engineering);

- low industrial demand for products with high value added;

- insufficient innovative activities of industrial enterprises, especially small ones, i.e. the passive attitude of businessmen to changes amid high exposure to uncertainty risks in the national economy;

- lack of necessary domestic machines, technological equipment, devises and so on for technological retrofitting, production refurbishment in leading sectors of the national economy, i.e. transport, telecommunications, chemical and food production;

- ownership structure, which still influences cluster residents' opportunities to finance their innovative activities with their own funds and resources, and their access to loans and other financial resources.

Previous researches corroborate that a cluster is an independent self-organized unit of the economy, that is capable of self-development using its own funds and resources, and reactivate business processes in the region and related industries. Assuming that the State may provide certain aid, the cluster may demonstrate even more impressive rates of economic and scientific development.

Considering the way European clusters are developed, cluster residents should focus on network connection parameters in their interactions, i.e. network access speed, rather than their geographic location and availability of resources. Remote access to the network 
resources requires the network to have remote regulators so to modify their state through the network (the technology was called virtual presence).

This particular approach, when products are created or services are delivered in the market through the network-based interaction of distributed resources owned by cluster residents, allows to choose the best business partners at the lowest cost. However, in most cases, this approach turns to be ineffective due to transaction costs that several residents incur in the process of their market interactions in the innovation-driven economy.

Cluster structures have a significant effect on the amount and nature of transaction costs. Currently, the transacting sector of the economy requires substantial information and technological resources, and lacks professional talent, thus seeking for the human potential.

Institutions of the information and innovation infrastructure incur tremendous transaction costs, thus causing respective expenditures among enterprises and individual businesses and the country, as a whole. That is why, currently, the transacting sector outlines the further direction of the global economic development.
Considering a continuing growth in transactions costs and the transacting sector, as a whole, the cooperation of cluster residents is not only an effective solution to the issue, but also eliminates those negative phenomena and consequences, which, for instance, arise from opportunistic behavior of suppliers or mala fide behavior of business partners.

Therefore, the positive synergistic effect from the interaction of entities within the cluster originates from reduced transaction costs relating to a search for information and partners, negotiations, conclusion of cooperation agreements, certification of ownership rights. The innovative and industrial cluster is an environmental system. It is the natural aquarium where professionals, who are shielded with information technologies and new knowledge, consolidate to attain the common goal and make the cluster prosperous.

Such territories will become centers of innovative development and capitalization of income. In the Russian Federation large industrial regions bring great hope because certain structural transformations are feasible there in pursuit of the fifth and sixth technological modes. Moscow oblast, Belgorod oblast and Ryazan oblast may be considered as such regions in terms of their total spending.

\section{Table 1}

Criteria and indicators for the analysis of the innovative potential of cluster member enterprises

\begin{tabular}{ll}
\hline $\begin{array}{l}\text { Criteria to evaluate the innovative potential } \\
\text { of entities within the cluster }\end{array}$ & Index \\
\hline Quantitative level of the innovative potential & \\
\hline $\begin{array}{l}\text { 1. Quantitative level of the cluster interaction } \\
\text { development }\end{array}$ & $\begin{array}{l}\text { The number of cluster residents. } \\
\text { The headcount of the entity within the cluster }\end{array}$ \\
\hline Qualitative level of the innovative potential & \\
\hline 2. Qualitative level of using the innovative potential & $\begin{array}{l}\text { Efficiency of interactions (common projects, initiative within the cluster), } \\
\text { time for agreement of project solution. } \\
\text { Qualitative level of the information support convergence evaluation }\end{array}$ \\
\hline $\begin{array}{l}\text { 2.1. Quality of information support } \\
\text { Openness level (public domain). } \\
\text { The level of support from authorities, community }\end{array}$ \\
\hline $\begin{array}{l}\text { 2.2. Quality of relationships with authorities } \\
\text { 2.3. The level of professional competence distribution }\end{array}$ & $\begin{array}{l}\text { Participation in conferences, meetings, business training, projects, webinars, forums } \\
\text { and social networks }\end{array}$ \\
\hline
\end{tabular}

Source:[6, p. 113] 
Table 2

The main regulators of revitalization of the cluster cooperation of enterprises and their functions

\begin{tabular}{|c|c|}
\hline Regulators & Regulator's functions \\
\hline 1. Governmental institutions & $\begin{array}{l}\text { Starting impulse: governmental institutions' support to start-up clusters. } \\
\text { Public private partnership: public and business structures consolidated to perform } \\
\text { joint projects. } \\
\text { Coordination: support to regional cluster initiatives and projects. } \\
\text { Innovation-focused entities of the cluster and cross-cluster interactions }\end{array}$ \\
\hline $\begin{array}{l}\text { 2. Global and national development of the information } \\
\text { economy }\end{array}$ & $\begin{array}{l}\text { Penetration of innovative products and technologies to new economic areas, } \\
\text { new markets }\end{array}$ \\
\hline 3. Hard technological tools for the cluster development & $\begin{array}{l}\text { New telecommunication networks. } \\
\text { New computers. } \\
\text { New communication devices }\end{array}$ \\
\hline 4. Soft intellectual and innovative tools & $\begin{array}{l}\text { Intellectual agents providing an access to information resources, open knowledge, } \\
\text { innovation (components of the business infrastructure of the cluster). } \\
\text { New competence of network-based (cluster) interaction specialists. } \\
\text { Knowledge database. } \\
\text { New software products }\end{array}$ \\
\hline 5. Local development of network structures & $\begin{array}{l}\text { Social networks. } \\
\text { Business community networks. } \\
\text { Hierarchical corporate organizations. } \\
\text { Network organizations. } \\
\text { Clusters }\end{array}$ \\
\hline
\end{tabular}

Source:[10, p. 92] 
Table 3

Incentives and disincentives of development of the cluster cooperation of enterprises

\begin{tabular}{lll}
\hline Factors & Incentives & Disincentives \\
\hline Endogenous & Active support of the government to the industrial sector & Political instability. \\
and clustering (development of national support programs). & Low development level of the national economy. \\
& Political and economic stability. & Disparities in the foreign currency sector. \\
Investment attractiveness. & Slow and unstable pace of national and regional \\
& Proximity of distribution markets. & development of the innovative infrastructure. \\
& Sufficiency of entities that may lead the market. & Red tape. \\
& Growing demand for innovative products and services of domestic & Poor urban infrastructure. \\
and foreign markets. & Nonexistent regulatory framework (certain gaps). \\
& High development level of the market infrastructure. & Low demand in the domestic market. \\
& Reliable ties with external partners. & Low confidence of investors, external partners. \\
& Tax regulation reforms. & Excessive attention of controlling authorities \\
& Positive image of the cluster residents' location & to the industrial sector. \\
& Rising tax burden. \\
& High emigration rates of specialists \\
\hline High quality of the domestic internal and technical infrastructure. & Scarce investment support. \\
Support of local authorities. & Nontransparent ownership structure. \\
Favorable business climate. & Mental barriers from poor confidence among partners. \\
& Active support of public communities. & Unpreparedness to risks. \\
High mutual confidence. & Spin-offs deteriorate cooperation trends. \\
Financial aid to investment projects of the cluster. & Substantial spending on business activities. \\
Ramified network of specialized educational institutions & Loss of customers. \\
and training centers. & Shortage of professional talent. \\
Robust core (coordinator) of the cluster. & Insufficient experience in financial integration. \\
Experience in successful activities in industrial production. & Nonexistent integral system of electronic \\
Smooth access to professional pipeline. & communications \\
Ramified informal contacts & \\
\hline
\end{tabular}

Source:Authoring

Please cite this article as: Abramov R.A., Podchufarov S.K. The Regional Innovation Potential of Industrial Clusters. Digest Finance, 2017, vol. 
Table 4

Analysis of the industry cluster status

\begin{tabular}{|c|c|c|c|c|c|c|c|c|c|}
\hline \multirow[t]{2}{*}{$\begin{array}{l}\text { Region } \\
\\
1\end{array}$} & \multirow[t]{2}{*}{$\begin{array}{l}\text { Food } \\
\text { production, } \\
\text { including } \\
\text { beverages and } \\
\text { tobacco } \\
2\end{array}$} & \multirow[t]{2}{*}{ 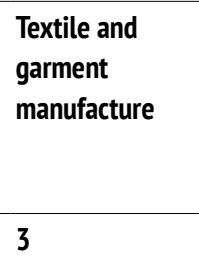 } & \multirow[t]{2}{*}{$\begin{array}{l}\text { Manufacture } \\
\text { of leather, } \\
\text { leather products } \\
\text { and footwear } \\
4\end{array}$} & \multicolumn{2}{|c|}{$\begin{array}{l}\text { Wood } \\
\text { processing and } \\
\text { manufacture } \\
\text { of wooden } \\
\text { products }\end{array}$} & \multicolumn{3}{|c|}{$\begin{array}{l}\text { Pulp and paper production, Coke and oil } \\
\text { publishing and printing production }\end{array}$} & $\begin{array}{l}\text { Chemical } \\
\text { production }\end{array}$ \\
\hline & & & & 5 & & 6 & & 7 & 8 \\
\hline Belgorod oblast & 3.166667 & - & - & - & & - & & - & - \\
\hline Bryansk oblast & 1.166667 & 1.6 & 0.366667 & 2.033 & 333 & - & & - & - \\
\hline Vladimir oblast & 1.133333 & 0.666667 & - & 0.766 & 667 & - & & - & 1.133333 \\
\hline Voronezh oblast & 0.633333 & 6.866667 & - & 0.933 & 333 & - & & - & 0.766667 \\
\hline Ivanovo oblast & - & 8.5 & - & 1.166 & 667 & - & & - & - \\
\hline Kaluga oblast & - & 0.733333 & - & 8.4 & & - & & - & - \\
\hline Kostroma oblast & - & 0.466667 & 0.666667 & 5.6 & & - & & - & 0.733333 \\
\hline Kursk oblast & 1.7 & 0.5 & 0.733333 & - & & 0.4333 & 333 & - & 0.766667 \\
\hline Lipetsk oblast & 1.266667 & - & - & 1 & & 0.7333 & 333 & - & 0.866667 \\
\hline Moscow oblast & 0.4 & - & - & 0.466 & & 0.3333 & 333 & - & 0.4 \\
\hline Orel oblast & 0.533333 & 0.466667 & 2.8 & - & & - & & 0.666667 & 0 \\
\hline Ryazan oblast & - & 1 & 1.833333 & 1.933 & & - & & 0.433333 & 0.866667 \\
\hline Smolensk oblast & - & 1.633333 & 5.166667 & 2.733 & 333 & - & & - & 0.633333 \\
\hline Tambov oblast & 0.733333 & 0.633333 & 0.633333 & - & & - & & - & 2.4 \\
\hline Tver oblast & - & 0.766667 & 5.233333 & 1.066 & 667 & - & & - & 0.666667 \\
\hline Tula oblast & - & - & - & - & & 1.2 & & 2.066667 & 1.1 \\
\hline Yaroslavl oblast & 1.166667 & - & 0.833333 & - & & - & & - & 0.4 \\
\hline Moscow & 0.4 & 0.6 & - & 0.666 & & 0.5 & & 0.866667 & - \\
\hline \multicolumn{10}{|l|}{ Continued } \\
\hline Region & $\begin{array}{l}\text { Manufacture } \\
\text { of rubber and } \\
\text { plastic } \\
\text { products }\end{array}$ & $\begin{array}{l}\text { Manufacture } \\
\text { of other nonmetal } \\
\text { mineral products }\end{array}$ & \multicolumn{2}{|c|}{$\begin{array}{l}\text { Metallurgical } \\
\text { tal production and } \\
\text { s production } \\
\text { of finished metal } \\
\text { products }\end{array}$} & \multicolumn{2}{|c|}{$\begin{array}{l}\text { Production } \\
\text { of machines } \\
\text { and equipment }\end{array}$} & $\begin{array}{l}\text { Production of electrica } \\
\text { equipment, electronic } \\
\text { and optic equipment }\end{array}$ & $\begin{array}{l}\text { cal Production } \\
\text { c of motor } \\
\text { vehicles and } \\
\text { equipment }\end{array}$ & $\begin{array}{l}\text { Other } \\
\text { production }\end{array}$ \\
\hline 1 & 9 & 10 & 11 & \multicolumn{3}{|c|}{12} & 13 & 14 & 15 \\
\hline Belgorod oblast & - & 2.933333 & 0.866667 & \multicolumn{3}{|c|}{-} & - & 1.166667 & - \\
\hline Bryansk oblast & 0.8 & 0.833333 & 0.866667 & \multicolumn{3}{|c|}{1.466667} & - & 1.433333 & 0.6 \\
\hline Vladimir oblast & 0.466667 & 0.466667 & - & \multicolumn{3}{|c|}{0.466667} & 0.566667 & 0.333333 & 0.5 \\
\hline $\begin{array}{l}\text { Voronezh } \\
\text { oblast }\end{array}$ & - & 0.366667 & - & \multicolumn{3}{|c|}{0.433333} & - & - & 3.766667 \\
\hline Ivanovo oblast & - & - & 0.333333 & \multicolumn{3}{|c|}{3.733333} & 7.266667 & 0.366667 & 0.366667 \\
\hline Kaluga oblast & - & - & - & \multicolumn{3}{|c|}{-} & 0.866667 & 1.666667 & 0.366667 \\
\hline $\begin{array}{l}\text { Kostroma } \\
\text { oblast }\end{array}$ & 0.8 & - & - & \multicolumn{3}{|c|}{-} & - & 0.333333 & 3.4 \\
\hline Kursk oblast & 0.833333 & 6.933333 & 1.266667 & \multicolumn{3}{|c|}{-} & 0.333333 & 0.566667 & - \\
\hline Lipetsk oblast & 1.4 & - & 3.233333 & \multicolumn{3}{|c|}{0.333333} & - & 0.466667 & - \\
\hline Moscow oblast & 0.633333 & 0.566667 & 0.8 & \multicolumn{3}{|c|}{0.6} & - & - & 0.366667 \\
\hline Orel oblast & - & 0.7 & 0.533333 & \multicolumn{3}{|c|}{1.866667} & - & - & - \\
\hline Ryazan oblast & 0.933333 & 0.866667 & - & \multicolumn{3}{|c|}{0.733333} & 0.666667 & - & 0.833333 \\
\hline
\end{tabular}




\begin{tabular}{llllllll}
\hline $\begin{array}{l}\text { Smolensk } \\
\text { oblast }\end{array}$ & 1.566667 & 0.533333 & - & - & 1.733333 & 0.333333 & 1.466667 \\
\hline Tambov oblast & - & 1.633333 & - & 0.366667 & 0.533333 & - & - \\
\hline Tver oblast & 2.1 & - & 0.933333 & 0.666667 & 1.4666667 & 0.966667 & 0.366667 \\
\hline Tula oblast & - & 0.333333 & 0.566667 & 0.8 & - & - & - \\
\hline Yaroslavl oblast & 0.8 & 1.2 & - & 0.5 & 0.366667 & 2 & - \\
\hline Moscow & 0.4 & - & 0.433333 & 0.5 & 0.333333 & 0.4 & 0.6 \\
\hline
\end{tabular}

Source:[10, p. 41]

\section{Table 5}

Types and importance of strategic defense

\begin{tabular}{|c|c|c|c|}
\hline Type of strategic safeguard & Security level $Y_{6}$ & $\begin{array}{l}\text { The nature of relative } \\
\text { value }\end{array}$ & Significance of coefficient $K_{6}$ \\
\hline $\begin{array}{l}\text { 1. Control over the standard that is generally } \\
\text { accepted in the market }\end{array}$ & 5 & Structures & Market share \\
\hline 2. Manufacture of products with cascading revenue & 5 & Comparison & Sales margin \\
\hline $\begin{array}{l}\text { 3. Holding the brand with the multiplicative effect } \\
\text { of product manufacture }\end{array}$ & 5 & Comparison & Sales margin \\
\hline $\begin{array}{l}\text { 4. Control over the pyramid commodity structure of } \\
\text { the market }\end{array}$ & 㝨 & Comparison & $\begin{array}{l}\text { Percentage of coverage of the pricing } \\
\text { range in the commodity pyramid }\end{array}$ \\
\hline $\begin{array}{l}\text { 5. Multiple component product supply (consumption } \\
\text { solutions = basic product + additional goods and } \\
\text { services) }\end{array}$ & 5 & Comparison & $\begin{array}{l}\text { Multiplier of profit growth in the } \\
\text { cluster }\end{array}$ \\
\hline 6. Dominance in the value creation chain & 4 & Comparison & $\begin{array}{l}\text { Multiplier of profit growth } \\
\text { in the cluster }\end{array}$ \\
\hline 7. Patent protection of the technological cycle & + & Structure & $\begin{array}{l}\text { Percentage of coverage } \\
\text { of the production cycle }\end{array}$ \\
\hline 8. Registered trademark & 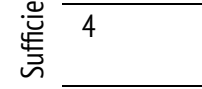 & Structure & $\begin{array}{l}\text { Public awareness (percentage } \\
\text { of knowledge with hint) }\end{array}$ \\
\hline 9. Consumer base for sale of ancillary goods & 4 & Comparison & $\begin{array}{l}\text { Percentage of ancillary products sold } \\
\text { to basic consumers (general } \\
\text { distribution) }\end{array}$ \\
\hline $\begin{array}{l}\text { 10. Release of novelties (renewals) with a two year } \\
\text { lag from leading competitors }\end{array}$ & 3 & - & 0 or 1 \\
\hline 11. Leadership in transactions & $\frac{\overline{\bar{z}}}{\bar{\alpha}}$ & - & 0 or 1 \\
\hline 12. Versatile organization structure of the cluster & $\sum^{\infty}$ & - & 0 or 1 \\
\hline 13. Leadership in the global (regional) market & 3 & - & 0 or 1 \\
\hline $\begin{array}{l}\text { 14. Release of novelties (renewals) with a year lag } \\
\text { from leading competitors }\end{array}$ & 2 & - & 0 or 1 \\
\hline 15. Leadership in the regional (local) market & 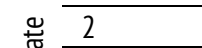 & - & 0 or 1 \\
\hline $\begin{array}{l}\text { 16. Leadership of cluster entities in terms } \\
\text { of spending }\end{array}$ & $\frac{\pi}{2}$ & - & 0 or 1 \\
\hline $\begin{array}{l}\text { 17. Technological diversification of supply } \\
\text { for the market }\end{array}$ & 2 & - & 0 or 1 \\
\hline 18. Deep specialization of production & 1 & - & 0 or 1 \\
\hline $\begin{array}{l}\text { 19. Parity of the cluster and the leader in terms } \\
\text { of spending }\end{array}$ & - & - & 0 or 1 \\
\hline 20. Lagging from the leader in terms of costs & 1 & - & 0 or 1 \\
\hline
\end{tabular}

Source:Authoring

Please cite this article as: Abramov R.A., Podchufarov S.K. The Regional Innovation Potential of Industrial Clusters. Digest Finance, 2017, vol. 


\section{References}

1. Sogacheva O.V. [Cluster analysis as a tool for socio-economic development of the region: Evidence from the Central Federal District]. Teoriya i praktika servisa: ehkonomika, sotsial'naya sfera, tekhnologii, 2016, no. 1, pp. 43-46. (In Russ.)

2. Komarova A.S. [Cluster analysis of human capital development in a selected region: Evidence from the Central Federal District of the RF]. Nauchnye issledovaniya i razrabotki. Ekonomika = Scientific Research and Development. Economy, 2015, vol. 3, no. 5, pp. 49-52. (In Russ.) doi: http://dx.doi.org/10.12737/13594

3. Filonova E.S. Vnutrennie ugrozy razvitiya Tsentral'nogo federal'nogo okruga. V kn.: Natsional'naya bezopasnost' Rossii: ekonomicheskie, politicheskie i informatsionnye mekhanizmy [Internal threats to the development of the Central Federal District. In: The national security of Russia: economic, political and information mechanisms]. Orel, Kartush Publ., 2015, pp. 69-83.

4. Babkin V.A. [Prerequisites formation of control facilities model of strategic management of innovative clusters]. Ekonomika i predprinimatel'stvo = Journal of Economy and Entrepreneurship, 2016, no. 2-1, pp. 1165-1171. (In Russ.)

5. Vertakova Yu.V., Risin I.E., Treshchevskii Yu.I. [Iterative clustering evaluation technology in regional economic space]. Ekonomika i upravlenie = Economics and Management, 2016, no. 4, pp. 11-19. (In Russ.)

6. Orlova I.V., Filonova E.S. [Cluster analysis of regions of the Central Federal District by socio-economic and demographic indicators]. Statistika i Ekonomika = Statistics and Economics, 2015, no. 5, pp. 111-115. (In Russ.)

7. Skvortsov E.N., Gus'kova N.D. [Analysis of the institutional structures of control systems of innovative industrial clusters in Russia]. Nauchno-tekhnicheskie vedomosti Sankt-Peterburgskogo gosudarstvennogo politekhnicheskogo universiteta. Ekonomicheskie nauki = St. Petersburg State Polytechnic University Journal. Economics, 2016, no. 1, pp. 86-99. (In Russ.)

8. Ivanenko L.V., Ivanenko A.A. [Innovation in the management of a regional cluster]. Vestnik Povolzhskogo gosudarstvennogo universiteta servisa. Ser. Ekonomika = Vestnik of Volga Region State University of Service. Ser. Economics, 2016, no. 1, pp. 87-93. (In Russ.)

9. Shedyakov V.E. [Innovative Systems of Regional Clusters' Management]. Regional'naya ekonomika i upravlenie = Regional Economics and Management, 2016, no. 4, pp. 98-103. (In Russ.)

10. Sergienko E.S. [A study of regional industrial clusters]. Ekonomika $v$ promyshlennosti = Economy in the Industry, 2014, no. 4, pp. 84-94. (In Russ.)

11. Kostenko O.V. [A strategy of enterprises' participation in the cluster: Search for areas of cooperation and collaboration]. Fundamental'nye issledovaniya = Fundamental Research, 2016, no. 9-3, pp. 601-606. (In Russ.)

12. Linev I.V. [Emergence and multiplier effects in the cluster]. Vestnik Voronezhskogo gosudarstvennogo universiteta inzhenernykh tekhnologii = Proceedings of Voronezh State University of Engineering Technologies, 2016, no. 2, pp. 378-383. (In Russ.)

13. Abramov R.A., Gilyadov T.G. [Regional features of modernization of the economy]. MIR (Modernizatsiya. Innovatsii. Razvitie) = MIR (Modernization. Innovation. Research), 2012, no. 8, pp. 31-34. (In Russ.)

14. Risin I.E., Sviridov A.S., Treshchevskii Yu.I. [Clustering of the socio-economic space of regions: hopes and realities]. Region: sistemy, ekonomika, upravlenie = Region: Systems, Economics, Management, 2015, no. 2, pp. 36-43. (In Russ.)

\section{Conflict-of-interest notification}

We, the authors of this article, bindingly and explicitly declare of the partial and total lack of actual or potential conflict of interest with any other third party whatsoever, which may arise as a result of the publication of this article. This statement relates to the study, data collection and interpretation, writing and preparation of the article, and the decision to submit the manuscript for publication. 